\title{
Optimalisasi Potensi Pajak dan Retribusi Daerah dalam Rangka Meningkatkan Pendapatan Asli Daerah di Kabupaten Ende
}

\author{
Sabra B. Wahab Thalib ${ }^{1}$ \\ Fakultas Ekonomi \\ Universitas Flores, Indonesia
}

\author{
Laurentius D. Gadi Djou² \\ Fakultas Ekonomi \\ Universitas Flores, Indonesia
}

\section{Ernesta Leha ${ }^{3}$ \\ Fakultas Ekonomi Universitas Flores, Indonesia}

\begin{abstract}
Surel : sabrawahabthalib@gmail.com
\section{ABSTRAK}

Tujuan dari penelitian ini adalah untuk menganalisis kontribusi, efektivitas dan efisiensi pajak dan retribusi daerah terhadap PAD. Untuk menganalisis persepsi masyarakat dan kendala dalam sistem pemungutan pajak dan retribusi daerah di Kabupaten Ende. Untuk merumuskan strategi kebijakan dalam optimalisasi penerimaan pajak dan retribusi daerah di Kabupaten Ende. Penelitian ini merupakan penelitian kuantitatif dan teknik pengambilan sampel menggunakan purposive sampling. Populasi yang digunakan adalah seluruh aparatur DPPKAD, dinas terkait, wajib pajak dan retribusi yang ada di Kabupaten Ende. Hasil penelitian menunjukkan bahwa kontribusi pajak dan retribusi daerah berada pada level sedang dan cukup baik. Efektivitas pajak dan retribusi daerah berada pada klasifikasi kurang efektif dan sangat efektif. Efisiensi pajak dan retribusi daerah berada pada posisi efisen. Sedangkan kendala yang dihadapi dalam konteks pajak dan retribusi daerah di Kabupaten Ende adalah masih kurangnya basis pajak dan retribusi yang dikelola oleh daerah.
\end{abstract}

Kata Kunci: Optimalisasi PAD; Pajak; Retribusi.

Optimalization Tax Potentials And Regional Retribution To Increase District Own Source Revenue In Ende Regency

\section{ABSTRACT}

The purpose of this research is to analyze the contribution, effectiveness and efficiency of taxes and retribution on PAD. To analize public perceptions and constraints in the system of collecting taxes and retribution in Ende district. To formulate policy strategies in optimizing local tax and retribution revenues in Ende district. This research is a quantitative research and the sampling technique uses purposive sampling. The population used is all DPPKAD apparatus, related agencies, tax and retribution payers in Ende regency. The results showed that the contribution of taxes and retribution is at a moderate level and is quite good. Effectiveness of taxes and retributions are classified as less effective and very effective. Efficiency of taxes and retribution is in an efficient position. Meanwhile, the obstacles faced in the context of local taxes and retribution in Ende regency are the lack of a base for taxes and retribution managed by the regions.

Keywords: $\quad$ PAD Optimalization; Tax; Retribution.

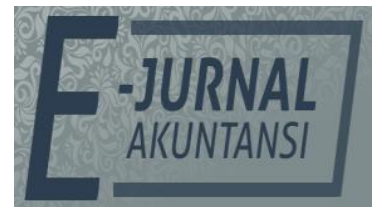

e-ISSN 2302-8556

Vol. 30 No. 10

Denpasar, Oktober 2020

Hal. 2627-2681

DOI:

10.24843/EJA.2020.v30.i10.p18

PENGUTIPAN:

Thalib, S. B. W., Djou, L. D.

G. \& Leha, E. (2020).

Optimalisasi Potensi Pajak dan Retribusi Daerah dalam

Rangka Meningkatkan

Pendapatan Asli Daerah di

Kabupaten Ende. E-Jurnal

Akuntansi, 30(10), 2627-2681

RIWAYAT ARTIKEL:

Artikel Masuk:

24 Desember 2019

Artikel Diterima:

26 Oktober 2020

Artikel dapat diakses : https://ojs.unud.ac.id/index.php/Akuntansi/index 


\section{PENDAHULUAN}

Pelaksanaan otonomi daerah telah mengubah sistem administrasi pemerintahan dan fiskal yang semula bersifat sentralisasi menjadi desentralisasi. Otonomi daerah merupakan pemberdayaan daerah dalam pengambilan keputusan yang lebih leluasa untuk mengelola potensi dan sumber daya yang dimiliki daerah tersebut. Dengan otonomi daerah yang luas, nyata, dan bertanggung jawab, setiap daerah dituntut untuk meningkatkan kemandirian daerahnya. Salah satu tolok ukur untuk melihat kesiapan daerah dalam pelaksanaan otonomi daerah adalah dengan mengukur seberapa besar kemampuan keuangan suatu daerah untuk menyelenggarakan pemerintahan sendiri yang mana sumber keuangan tersebut salah satunya berasal dari Pendapatan Asli Daerah atau PAD.

Dengan diberlakukannya Undang-Undang No.32 Tahun 2004 tentang Pemerintahan Daerah, setiap daerah diberi keleluasaan untuk menyelenggarakan urusan rumah tangganya sendiri tanpa campur tangan dari pemerintah pusat untuk kepentingan masyarakat setempat sesuai dengan peraturan perundang-undangan. Melalui strategi optimalisasi pajak dan retribusi, diharapkan pemerintah daerah juga akan mampu guna meningkatkan kemampuannya dalam penyelenggaraan urusan otonomi daerah khususnya terkait pendapatan asli daerah (PAD). Pendapatan asli daerah (PAD) merupakan pendapatan daerah yang bersumber dari hasil pajak daerah, hasil retribusi daerah, hasil pengelolaan kekayaan daerah yang dipisahkan, dan lain-lain pendapatn asli daerah yang sah, yang bertujuan untuk memberikan kewenangan kepada pemerintah daerah untuk mandanai pelaksanaan otonomi daerah sesuai dengan potensi daerah sebagai perwujudan desentralisasi (Penjelasan UU No. 33 Tahun 2004).

Upaya optimalisasi sumber pendapatan asli daerah selaras dengan tujuan otonomi daerah yakni menciptakan kesejahteraan masyarakat di daerah. Undang-undang No. 28 Tahun 2009 tentang Pajak Daerah dan Retribusi Daerah merupakan langkah strategis dalam upaya memberikan kewenangan yang lebih luas kepada daerah di bidang perpajakan daerah (local taxing power). Keberadaan UU No. 28 Tahun 2009 diharapkan akan dapat memberikan ruang gerak yang lebih longgar bagi daerah untuk melakukan pemungutan pajak daerah dan retribusi daerah, sesuai potensi dan kondisi masing-masing daerah.

Pajak dan retribusi daerah merupakan salah satu bentuk peran serta masyarakat dalam penyelenggaraan otonomi daerah. Pajak dan retribusi daerah merupakan sumber pendapatan daerah yang penting untuk membiayai penyelenggaraan pemerintahan dan pembangunan daerah. Menurut Mardiasmo (2016) pajak daerah adalah iuran wajib yang dilakukan oleh orang pribadi atau badan kepada daerah tanpa imbalan langsung yang seimbang yang dapat dipaksakan berdasarkan peraturan perundang-undangan yang berlaku yang digunakan untuk membiayai penyelenggaraan pemerintah daerah dan pembangunan daerah. Sedangkan retribusi daerah berdasarkan Undang-undang nomor 28 tahun 2009 adalah pungutan daerah sebagai pembayaran atas jasa atau pemberian izin tertentu yang khusus duseduakan dan atau diberikan oleh pemerintah daerah untuk kepentingan orang pribadi atau badan Maria Tupamahu, et al, (2019). Menurut Indra Bastian (2011), retribusi adalah pungutan yang dilakukan oleh Pemerintah Daerah atas pelayanan dan penggunaan 
fasilitas-fasilitas umum yang disediakan oleh pemrintah daeraah bagi kepentingan masyarakat sesuai dengan peraturan daerah yang berlaku.

Pemungutan Pajak Daerah dan Retribusi Daerah tidak lepas dari efektivitas dan efisiensi serta kontribusi terhadap PAD. Efektivitas adalah tingkat angka pencapaian pemerintah dalam memungut atau menarik Pajak Daerah dan Retribusi Daerah yang dibandingkan dengan target yang telah ditentukan sebelumnya. Efektivitas adalah keberhasilan atau kegagalan dari organisasi dalam mencapai tujuannya. Efisiensi adalah biaya yang dipakai pemerintah daerah dalam memberikan pelayanan jasa dengan tujuan mendapatkan keuntungan layak pada proses pemungutan Pajak Daerah dan Retribusi Daerah yang kemudian dibandingkan dengan jumlah keuntungan keseluruhan, serta perbandingan bersama target. Kontribusi adalah angka yang diberikan oleh Pajak Daerah dan Retribusi Daerah terhadap jumlah keseluruhan pada angka PAD yang dicapai maupun angka pada target yang ditetapkan (Rizky et al., 2014).

Dalam konteks Kabupaten Ende, terbitnya UU No. 28 tahun 2009 tersebut kemudian ditindaklanjuti dengan terbitnya peraturan daerah yang mengatur tentang pajak dan retribusi daerah. Pengelolaan Pajak daerah diatur dalam Perda No. 2 tahun 2011, dan Retribusi daerah diatur dalam 3 (tiga) jenis Perda yakni Perda No.3 tahun 2011 tentang Retribusi Jasa Umum, Perda No. 4 tahun 2011 tentang Retribusi Jasa Usaha dan Perda No.5 tahun 2011 tentang Retribusi Perizinan Tertentu. Keberadaan 4 (empat) jenis Perda tentang pajak dan retribusi daerah ini diharapkan menjadi landasan kuat dalam menggali potensi daerah di Kabupaten Ende. Namun faktanya, dari tahun ke tahun, penerimaan PAD dari sektor pajak dan retribusi daerah belum juga optimal.

Penerimaan PAD di Kabupaten Ende mengalami fluktuasi seiring dengan tidak stabilnya penerimaan pajak dan retribusi dari tahun ke tahun. Belum optimalnya realisasi penerimaan pajak dan retribusi daerah menunjukkan belum maksimalnya kontribusi PAD dalam mendanai pembangunan dan penyelenggaraan pemerintahan daerah di Kabupaten Ende. Ini berarti spirit desentralisasi fiskal dan otonomi daerah belum sejalan dalam proses pembangunan daerah di Kabupaten Ende dimana tujuan utama pelaksanaan otonomi daerah adalah meningkatkan kemandirian dan kreativitas daerah dalam mengatur dan menangani urusan daerah.

Berdasarkan kenyataan tersebut, kami melakukan kajian dengan judul “Optimalisasi Pajak dan Retribusi Dalam Rangka Meningkatkan Pendapatan Assli Daerah (PAD) di Kabupaten Ende". Adapun tujuan dari kajian ini adalah 1) Menganalisis kontribusi pajak dan retribusi daerah terhadap Pendapatan Asli Daerah di Kabupaten Ende, 2) Menganalisis efektivitas pajak dan retribusi daerah terhadap PAD Kabupaten Ende 3) Menganalisis efisiensi pajak dan retribusi daerah terhadap PAD Kabupaten Ende, 4) Menganalisis persepsi masyarakat dan kendala dalam sistem pemungutan pajak dan retribusi daerah Kabupaten Ende, 5) Merumuskan strategi kebijakan dalam optimalisasi penerimaan pajak dan retribusi di Kabupaten Ende? 


\section{METODE PENELITIAN}

Subjek dalam penelitian kuantitatif ini yakni seluruh aparatur DPPKAD, Dinas terkait dan seluruh Wajib Pajak yang ada di Kabupaten Ende. Jenis data yang dipakai adalah data sekunder dan data primer. Sumber data primer adalah Ende dalam Angka tahun 2013 sampai 2017 terbitan BPS Kabupaten Ende. Sedangkan data primer diperoleh melalui penyebaran kuesioner kepada responden (wajib pajak) untuk mengetahui persepsi wajib pajak dan stakehoder dari DPPKAD dan semua instansi yang terkait dengan pajak dan retribusi daerah. Salah satu teknik pengumpulan data dalam penelitian ini dengan menggunakan kuesioner yang terdiri dari 2 (dua) jenis yakni kuesioner untuk responden wajib pajak guna mengetahui persepsi masyarakat tentang sistem pemungutan pajak dan kuesioner untuk responden AHP untuk menentukan strategi prioritas optimalisasi pajak dan retribusi di Kabupaten Ende. Populasi dalam penelitian ini meliputi: 1) Seluruh aparatur Dinas Pendapatan Pengelolaan Keuangan dan Asset Daerah Kabupaten Ende dan semua dinas terkait, 2) Semua wajib pajak dan retribusi daerah yang ada di Kabupaten Ende yang akan diwawancarai secara terstruktur menggunakan kuesioner guna mengetahui dan memahami persoalan kendala dari sisi wajib pajak. Sampel dalam penelitian ini dibagi dalama dua kelompok yakni: 1) Sampel stakeholder pajak dari Kantor Dinas Pengelolaan Keuangan dan Asset Daerah dan instansi-instansi terkait yang ditentukan secara purposive sampling, 2) Sampel wajib pajak yang ditentukan dengan menggunakan rumus persamaan Slovin (Sevilla \& Consuelo, 1993) dan Uma Sekaran (2000) sebagai berikut.

$$
n=\frac{N}{1+\left(N(M o e)^{2}\right)}
$$

Dimana:

$\mathrm{n} \quad=$ jumlah sampel

$\mathrm{N} \quad=$ jumlah populasi

Moe = Margin of error Maximum (kesalahan yang masih ditoleransi diambil $10 \%)$

Untuk menentukan jumlah sampel sebagai responden pada setiap kecamatan dilakukan dengan metoda proportional random sampling. Alokasi penentuan anggota sampel dapat dilakukan sebagai berikut.

$n i=\frac{N i}{N} \times n$

Dimana:

ni $\quad=$ ukuran sampel dari kecamatan ke i

$\mathrm{Ni} \quad=$ populasi wajib pajak pada kecamatan ke $\mathrm{i}$

$\mathrm{N} \quad=$ populasi total wajib pajak

$\mathrm{n} \quad$ = jumlah sampel wajib pajak yang ditetapkan

Sampel dalam penelitian ini melibatkan 100 responden sampel dari 12

(dua belas) kecamatan dan 7 orang pakar yang dianggap mampu dan paham tentang seluk beluk persoalan pajak dan retribusi daerah di Kabupaten Ende. Teknik Pengambilan sampel dalam penelitian ini dengan menggunakan purposive sampling dan untuk menentukan jumlah sampel responden untuk 
setiap kecamatan dengan menggunakan metode proportional random sampling. Metode Analitytical Hierarchy Process (AHP) adalah suatu model yang digunakan untuk menyelesaikan persoalan yang kompleks, tidak terstruktur, strategik dan dinamik menjadi sebuah bagian yang tertata dalam suatu hierarki. Caranya adalah dengan memberikan nilai numerik secara subyektif pada setiap tingkat kepentingan setiap variabel dengan membandingkannya secara relatif dengan variabel lainnya. Dengan menggunakan AHP, sebuah persoalan akan diselesaikan dalam sebuah kerangka yang terorganisir sehingga dapat diekpresikan untuk mengambil keputusan yang efektif atas persoalan tersebut. Secara graphis, persoalan keputusan AHP dapat dikonstruksikan sebagai diagram bertingkat (hierarki). AHP dimulai dengan membuat goal/sasaran lalu kriteria level pertama, sub kriteria dan akhirnya alternatif. Terdapat berbagai bentuk hierarki keputusan yang disesuaikan dengan substansi dan persoalan yang harus diselesaikan dengan AHP.

\section{HASIL DAN PEMBAHASAN}

Selama ini PAD memiliki peran penting untuk membiayai pelaksanaan otonomi daerah guna mencapai tujuan utama penyelenggaraan otonomi daerah yakni untuk meningkatkan pelayanan publik dan memajukan perekonomian daerah (Mardiasmo, 2002:46). Pemda melakukan berbagai cara dalam meningkatkan pelayanan publik, yang salah satunya dilakukan dengan melakukan belanja untuk kepentingan investasi yang direalisasikan melalui belanja modal.

Tabel 1. Perkembangan PAD dan Pendapatan Daerah Kabupaten Ende Tahun 2009 - 2014

\begin{tabular}{crrc}
\hline Tahun & PAD & Pendapatan Daerah & $\begin{array}{c}\text { Rasio } \\
\text { PAD terhadap } \\
\text { Pendapatan Daerah }\end{array}$ \\
\hline 1 & 2 & 3 & 4 \\
\hline 2009 & $17.907 .712 .172,00$ & $451.121 .812 .291,00$ & 3,97 \\
2010 & $18.714 .079 .408,00$ & $461.238 .144 .683,00$ & 4,06 \\
2011 & $27.225 .311 .366,00$ & $572.517 .286 .359,00$ & 4,76 \\
2012 & $33.989 .650 .232,00$ & $641.497 .808 .175,00$ & 5,30 \\
2013 & $41.351 .518 .661,00$ & $697.489 .945 .572,00$ & 5,93 \\
2014 & $61.000 .829 .122,68$ & $772.689 .981 .458,68$ & 7,90 \\
& Rata-rata & & 5,32 \\
\hline
\end{tabular}

Sumber : Bappeda, DPPKAD, 2009-2014

Dari Tabel 1, nampak bahwa sejak tahun 2009 sampai tahun 2014 terlihat adanya peningkatan PAD tetapi dengan persentasi yang sangat kecil yakni dari $3,97 \%$ menjadi 7,90 persen. Dengan nilai rata-rata rasio sebesar 5,32 menunjukkan bahwa kontribusi PAD terhadap pendapatan daerah berada pada level "sangat kurang".

Permasalahan yang dihadapi oleh daerah pada umumnya dalam kaitan penggalian sumber-sumber pajak daerah dan retribusi daerah, yang merupakan salah satu komponen dari PAD, adalah belum adanya kontribusi yang signifikan terhadap penerimaan daerah secara keseluruhan. Perhitungan kontribusi ini 
digunakan untuk mengetahui seberapa besar sumbangsih pajak dan retribusi daerah terhadap pendapatan asli daerah. Berdasarkan hasil analisis data pajak dan retribusi daerah di Kabupaten Ende selama 6 (enam) tahun terlihat bahwa antara pajak dan retribusi, nilai rasio yang lebih tinggi adalah retribusi daerah sebesar 31,52\%. Ini berarti kontribusi retribusi terhadap PAD berada pada level cukup baik, sama dengan level kriteria untuk komponen PAD yang lain yakni lain-lain Pendapatan asli daerah yang sah. Sedangkan pajak dengan nilai rasio rata-rata sebesar $21,14 \%$ menempati level kriteria sedang dan yang paling rendah kontribusinya adalah komponen hasil kekayaan daerah yang dipisahkan dengan nilai rasio sebesar 7, 26 yang berada pada level sangat kurang.

Berdasarkan jenisnya, pajak yang dipungut di kabupaten Ende terdiri dari 9 jenis. Dan dari 9 jenis pajak tersebut, pencapaian terbesar ada pada pajak hotel dengan persentase 229,95\% namun dengan nilai realisasi yang lebih kecil dibandingkan pajak lain sebesar Rp. 119.571.000. Kontribusi terbesar secara nominal adalah pajak penerangan jalan sebesar $49,76 \%$ atau dengan nilai Rp. 4.183.389.409,00. Kontribusi terkecil ada pada jenis pajak hiburan dengan nilai 0,18\% atau Rp.25.000.000. Secara umum kondisi penerimaan dari setiap jenis pajak berada pada level 'kurang" bahkan "sangat kurang', kecuali pajak penerangan jalan yang berada pada level "baik'. Walaupun kondisi ini tidak dibarengi dengan peningkatan kualitas layanan penerangan jalan di Kabupaten Ende.

Retribusi di Kabupaten Ende terdiri dari 3 macam yakni Retribusi Jasa Umum, Retribusi Jasa Usaha dan Retribusi Perijinan Tertentu. Masing-masing retribusi memiliki $6-7$ jenis item retribusi dengan kontribusi yang bervariasi antar setiap jenisnya. (Lihat lampiran). Berdasarkan hasil analisis data diketahui bahwa kontribusi terbesar terhadap retribusi daerah adalah adalah dari sisi retribusi jasa umum sebesar 77,17\% atau berada pada level "sangat baik" dengan nilai nominal Rp. 5.068.878.600,-. Sedangkan kontribusi dari komponen retribusi jasa usaha sebesar 17,25 atau berada pada level "kurang" dan yang paling rendah adalah dari retribusi perizinan tertentus ebesar 5,58 atau berada berada level "sangat kurang".

Efektivitas adalah keberhasilan atau kegagalan dari organisasi dalam mencapai tujuannya. Berdasarkan hasil analisis data pajak dan retribusi daerah Kabupaten Ende terlihat bahwa nilai rata-rata realisasi pajak selama 6 tahun sebesar $75,88 \%$ yang berarti pemungutan pajak daerah berada pada klasifikasi "kurang efektif". Sedangkan nilai rata-rata realisasi retribusi daerah sebesar 102, 92\% yang berarti pemungutan retribusi 'sangat efektif' karena berada di atas $100 \%$. Demikian halnya dengan realisasi hasil pengelolaan kekayaan daerah yang dipisahkan dan Lain-lain pendapatan asli daerah yang sah, rasionya di atas $100 \%$ sehingga dapat dikatakan sangat efektif.

Efisiensi pajak dan retribusi daerah adalah nilai yang dihitung berdasarkan presentase perdagangan biaya pemungutan retribusi dengan realisasi penerimaan pajak dan retribusi. Kriteria yang digunakan dalam menilai efisiensi pajak dan retribusi daerah adalah jika rasio efisiensi atau biaya pemungutan terhadap total realisasi pajak dan retribusi tidak lebih dari 5\%, maka pengelolaannya dinyatakan efisien. Demikian sebaliknya, jika nilai efisiensi berada di atas 5\% maka dinyatakan "tidak efisien" (Keputusan Menteri Dalam 
Negeri No. 35 Tahun 2002) . Dari hasil analisis data pajak dan retribusi di Kabupaten Ende diketahui bahwa semua komponen PAD yakni pajak, retribusi, hasil pengelolaan kekayaan daerah yang dipisahkan serta lain-lain PAD yang sah berada pada level di bawah 5\% . Ini berarti pengelolaan pajak dan retribusi daerah serta komponen lainnya sudah " efisien".

Analisis deskriptif kualitatif dilakukan melalui wawancara terstruktur terhadap responden sebanyak 100 orang di 12 (dua belas) kecamatan di Kabupaten Ende. Wawancara ini dilakukan untuk mengetahui persepsi masyarakat tentang sistem pemugutan pajak dan retribusi daerah yang dilakukan oleh DPPKAD dan SKPD terkait. Hal ini penting agar penilaian dalam kajian ini seimbang, baik dari perspektif pengelola PAD, masyarakat selaku wajib pajak maupun stakeholder yang diposisikan sebagai pakar atau narasumber yang paham tentang pajak dan retribusi daerah. Berikut hasil wawancara tentang persepsi masyarakat terkait pajak dan retribusi daerah.

Dari total responden yang diwawancarai sebanyak 100 orang yang tersebar di 12 kecamatan diketahui bahwa persepsi masyarakat tentang tingkat kewajaran nilai pajak dan retribusi saat ini masih dalam tahap "wajar", yang dicerminkan oleh skor persentase sebesar $65 \%$. Sedangkan yang lainnya menyatakan terlalu tinggi sebesar $29 \%$ dan yang menyatakan tidak tahu sebesar $6 \%$. Ini merupakan sinyal positif bagi Pemda untuk meningkatkan realisasi penerimaan PAD khususnya dari sisi pajak dan retribusi daerah. Untuk besaran pajak dan retribusi daerah, hasil analisis persepsi masyarakat menunjukkan bahwa yang menyatakan nilai pajak tetap sebesar $48 \%$, naik $20 \%$ dan berubah-ubah sebanyak $28 \%$. Sedangkan untuk tingkat pelayanan petugas pemungut pajak, ditemukan sering terjadinya kecurangan yang dilakukan oleh petugas dimana satu karcis retribusi digunakan untuk 2 orang atau lebih. Kasus ini banyak terjadi di beberapa wilayah yang potensial bagi retribusi seperti pasar dan parkiran. Namun secara umum responden menyatakan bahwa pelayanan petugas pajak "baik" dengan skor 61\%, "kurang baik" sebanyak 12\% dan cukup baik sebesar $11 \%$.

Dari hasil analisis data kontribusi dan efektivitas terlihat bahwa pemungutan pajak dan retribusi daerah di Kabupaten Ende belum maksimal. Kondisi ini tercermin pada sistem dan prosedur pemungutan yang masih konvensional dan masih banyaknya sistem yang berjalan secara parsial, sehingga besar kemungkinan informasi yang disampaikan tidak konsisten, versi data yang berbeda-beda dan data tidak up-to-date. Permasalahan pada sistem pemungutan pajak di kabupaten Ende cukup banyak, baik secara internal pengelola pajak dan retribusi maupun persoalan eksternal, dari sisi wajib pajak. Persoalan internal yang ditemukan dalam kajian ini adalah dalam hal data wajib pajak/retribusi, penetapan jumlah pajak dan retribusi, jumlah tagihan dan target pemenuhan pajak dan retribusi yang tidak optimal. Sedangkan persoalan eksternal adalah masalah pemahaman dan kesadaran wajib pajak yang rendah. Dari hasil wawancara dengan para stakeholder, ada dua hal penting yang ditemukan dalam konteks sistem pemungutan pajak di Kabupaten Ende yakni, 1) Persoalan perilaku wajib pajak dan 2) Kreativitas Pengelola wajib pajak yang rendah.

Penyusunan hirarki dilakukan dengan cara mengidentifikasi pengetahuan dan informasi yang sedang diamati. Penyusunan tersebut dimulai dari 
permasalahan yang kompleks yang diuraikan menjadi elemen pokok dan elemen pokok diuraikan lagi menjadi bagian- bagian tertentu secara hirarki. Dalam kajian ini, susunan hirarki terdiri dari goal, sasaran, kendala, aktor dan strategi kebijakan.

Hasil penetapan nilai peringkat untuk setiap kriteria/ pilihan melalui pembobotan pada masing-masing responden berdasarkan nilai skala perbandingan dari angka satu sampai sembilan, kemudian dikelompokkan ke dalam matriks perbandingan sekaligus perhitungan nilai prioritas totalnya. Hasil kombinasi jawaban 7 responden dengan metode AHP diperoleh sebagai berikut: 1) Hasil kompilasi jawaban semua responden menunjukkan bahwa elemen sasaran yang mendapatkan prioritas jawaban terbanyak adalah peningkatkan akses Pemda dalam perencanaan program pembangunan daerah sebesar 0,599 atau $59,9 \%$. 2) Hasil pembobotan elemen sasaran terhadap kendala menunjukkan bahwa bobot tertinggi untuk elemen kendala adalah rendahnya motivasi dan kesadaran masyarakat dalam membayar pajak dan retribusi daerah sebesar 0,340 atau $34,0 \%$ dengan sasaran meningkatkan askes pemda dalam perencanaan program pembangunan, 3) Pembobotan elemen kendala terhadap elemen aktor menunjukkan bahwa skor tertinggi ada pada kendala rendahnya kesadaran masyarakat dengan stakeholder yang paling berpengaruh adalah DPPKAD dengan skor 0,343 atau 34,3\%. 4) Hasil pembobotan elemen Kendala terhadap elemen aktor berdasarkan sasaran penyediaan dan peningkatan kualitas pelayanan publik menunjukkan bahwa skor tertinggi adalah Sistem Manajemen PAD yang belum memadai dengan skor 0,238 atau $23,8 \%$ dan stakeholder yang memiliki peran penting adalah DPPKAD dan Dinas Terkait $(0,220$ atau 22,2\%), 5) Hasil akhir dari perhitungan AHP menunjukkan skor tertinggi berada pada strategi pertama yakni sosialisasi meningkatkan motivasi dan kesadaran wajib pajak sebesar 0,293 atau 29,3\%.

\section{SIMPULAN}

Berdasarkan hasil survey di 12 Kecamatan Kabupaten Ende terlihat bahwa kesadaran dan motivasi masyarakat untuk membayar pajak masih sangat rendah. Ini berarti persoalan utama belum optimalnya potensi pajak dan retribusi dalam meningkatkan PAD di Kabupaten Ende bukan pada kesalahan mengestimasi target atau potensi tetapi justru terletak pada persoalan perilaku baik dari sisi masyarakat selaku wajib pajak maupun dari sisi pemungut pajak selaku pengelola Pendapatan Asli Daerah. Selain itu, tingkat kejujuran dan ketaatan dari para pelaku usaha sebagai wajib pajak juga masih sangat memprihatinkan. Hal ini terlihat dari banyaknya upaya penghindaran dan penggelapan pajak yang dilakukan oleh para wajib pajak dengan cara tidak melaporkan omzet usaha dan penghasilannya secara jujur. Bentuk penghindaran pajak ini tidak hanya terjadi di sektor usaha seperti restorant, rumah makan dan hotel tetapi juga terjadi dalam setiap bentuk transaksi yang berkaitan dengan pajak, seperti transaksi jual beli tanah dimana Nilai Jual Obyek Pajak atau NJOP selalu dibuat lebih rendah dari nilai riilnya. Ini berarti strategi unggulan berdasarkan pendapat para responden (pakar) yang dianalisis dengan metode AHP adalah sosialisasi meningkatkan kesadaran dan motivasi wajib pajak. 
Saran yang dapat di sampaikan dari hasil penelitian ini kepada Pemerintah Daerah Kabupaten Ende dalam rangka untuk meningkatkan Pendapatan Asli Daerah (PAD) yaitu Pemerintah Daerah harus memperluas basis penerimaan pajak dan retribusi daerah, memperbaiki sistem manajemen PAD melalui peningkatan efektivitas dan mempertahankan efisiensi pemungutan pajak dan retribusi daerah, meningkatkan kapasitas penerimaan melalui perencanaan yang lebih baik, Pembenahan Sistem Manajemen PAD melalui peningkatan kualitas SDM serta meningkatkan kinerja Dinas-dinas yang terkait dengan retribusi dan pajak daerah. Selain itu tingkat pencapaian Pajak Daerah dan Rertibusi atas target yang selalu meningkat sudah sangat baik/efektif, namun tetap memperhatikan konsistensi yang selaras dengan tren persentesenya karena terlihat naik dan turun(fluktuatif), serta kontribusinya perlu ditingkatkan. Perlu diadakan upaya-upaya untuk meningkatkan hasil PAD khususnya Pajak Daerah dan Retribusi Daerah. Penurunan perolehan PAD dari sektor Retribusi Daerah kiranya mendapatkan perhatian serius, evaluasi, dan ditingkatkan semaksimal mungkin karena tren kontribusi yang terus turun.

\section{REFERENSI}

Aristanty Widyanigsih; (2011), "Hukum Pajak Daerah, Perpajakan), Bandung Badan Pusat Statistik. (2017). "Ende Dalam Angka”. BPS Kabupaten Ende Badan Pusat Statistik, (2016). "Ende Dalam Angka". BPS Kabupaten Ende Badan Pusat Statistik, (2015). "Ende Dalam Angka". BPS Kabupaten Ende Bratakusumah, Deddy Supriady et al., (2016). "Otonomi Penyelenggaraan Pemerintah Daerah". Gramedia Pustaka Utama, Jakarta.

Halim, Abdul. (2015), "Manajemen Keuangan Daerah, Bunga Rampai", UPP AMP YKPN, Edisi Pertama, Yokyakarta. Indra., Bastian. (2011). "Manual Akuntansi Keuangan Pemerintah Daerah". Yogyakarta. Penerbit BPFE

Indah Ayu Sulviane., Harianto.,dan Dedi Budiman Hakim. (2014). "Strategi Peningkatan Pendapatn Pajak Reklame DiKabupaten Bogor". Jurnal Manajemen Pembangunan Daerah. Volume 6 Nomor 1.

Mardiasmo., (2016). "Perpajakan Edisi Revisi". Yogyakarta : Penerbit Andi.

Marimin dan Nurul Maghfiroh. (2011). "Aplikasi Teknik Pengambilan Keputusan". PT Penerbit IPB Press. Bogor

Marimin. (2015). “Teori Aplikasi Sistem Pakar dan Teknologi Manajerial”. IPB Press.Bogor

Mardiasmo. (2015). “Otonomi dan Manajemen Keuangan Daerah". Penerbit Andi, Yogyakarta

OECD (1999): "Taxing Powers Of State and Local Government", OECD Publication Service, France.

Republik Indonesia, Undang-undang No.32 Tahun 2014 Tentang Pemerintahan Daerah".

Beberapa Peraturan pelaksanaan dari UU No.32 Tahun 2004 dan

UU No.33 Tahun 2004.

Republik Indonesia, Nota Keuangan dan RAPBN Tahun Anggaran 2015. 
Rizky, E., Puspitasari, A., \& Rohman, A. (2014). Analisis Efektivitas, Efisiensi, Dan Kontribusi Pajak Daerah Dan Retribusi Daerah Terhadap Peningkatan Pad Kabupaten Blora Tahun 2009-2013. Diponegoro Journal of Accounting, 0(0), 133-147. Siahaan, Marihot, (2005), "Pajak Daerah dan Retribusi Daerah". Rajawali Pers. Jakarta.

Soeboko, S., \& Riyad, A., “Sumber Daya Manusia Dalam Otonomi Daerah". Jurnal Ekonomi Pembangunan. Kajian Masalah Ekonomi dan Pembangunan. http://doi.org/10.23917/jep.vlil.3888

Ter-Minassian,Teresa (1997), "Fiscal Federalism in Theory and Practice", International Monetary Fund, Washington.

Undang-Undang Republik Indonesia Nomor 33 Tahun 2004, Tentang Perimbangan Keuangan Antara Pemerintah Pusat dan Pemerintahan Daerah. www.djlp.esdm.go.id.

Undang-Undang Republik Indonesia Nomor 32 Tahun 2014, Tentang Pemerintahan Daerah. www.djlp.esdm.go.id. 